\title{
Kimberlite ascent and eruption
}

\author{
Arising from: L. Wilson \& J. W. Head III Nature 447, 53-57 (2007).
}

Wilson and Head ${ }^{1}$ model kimberlite ascent and eruption by considering the propagation of a volatile-rich dyke. Wilson and Head's model has features in common with Sparks et al. ${ }^{2}$, but it is inconsistent with geological observations and constraints on volatile solubility. Here we show that this may be due to erroneous physical assumptions.

Dyke propagation is dependent on balances between buoyancy, source pressure and fracture strength ${ }^{3,4}$. Wilson and Head assume that kimberlite dykes are connected to the deep source and that the pressure gradient between the source and the dyke tip is governed by the release of copious carbon dioxide $\left(\mathrm{CO}_{2}\right)$. Thus, assumptions are made about the volume of available magma, $\mathrm{CO}_{2}$ solubility and volatile composition, as well as about whether source pressure or buoyancy is dominant and about the behaviour of volatiles released into the crack tip. Wilson and Head state that $90 \%$ of the $\mathrm{CO}_{2}$ is exsolved at $2 \mathrm{GPa}$. However, $\mathrm{CO}_{2}$ becomes increasingly soluble as melts become more silica-deficient ${ }^{5}$; at $100 \mathrm{MPa}$, silica-poor basic melts can dissolve $>1 \% \mathrm{CO}_{2}$ and, with a linear solubility law, most if not all $\mathrm{CO}_{2}$ would be dissolved at $2 \mathrm{GPa}$. Furthermore, in carbonate-rich melts, most carbon is speciated as carbonate rather than molecular $\mathrm{CO}_{2}$, as indicated by magmatic calcite in hypabyssal kimberlites ${ }^{6}$. The Wilson and Head model overestimates the amount of volatiles available to act as an exsolving propellant. Water may be a major volatile in kimberlite ${ }^{2}$, but it only exsolves at low pressure.

In the model of Wilson and Head, volatiles are released from exsolving magma into the dyke tip with a very low pressure, resulting in very high pressure gradients and very high propagation speeds (tens of metres per second). However, experimental and theoretical studies $^{4,7}$ show that the much larger buoyancy of released volatiles results in a fluid-filled fracture accelerating in advance of the magmafilled dyke, consistent with observations from kimberlite dykes ${ }^{8}$. The pressure in the volatile-filled fracture moving in advance of and accelerating away from the magma must be at least the lithostatic pressure plus the mantle fracture strength, so we question the very low pressures, except for a negligibly small region at the volatile-filled crack tip ${ }^{3,4}$. Wilson and Head infer a decelerating fracture system, whereas previous work $\mathrm{k}^{9}$ on dyke nucleation indicates that acceleration is a consequence of the increase in length as dykes propagate and decompress.

There are difficulties reconciling the very short eruption times estimated by Wilson and Head and the geological complexity of kimberlites $^{2}$ (C. R. Clement et al., unpublished results), which indicate prolonged multistage eruptions. Furthermore, constraints on volumes and magma supply rates through established dyke systems ${ }^{2}$ indicate eruption times of days to months rather than an hour. Wilson and Head estimate large adiabatic coolings, but these are not consistent with estimates of high emplacement temperatures $\left(>400{ }^{\circ} \mathrm{C}\right.$ to $\left.1,100{ }^{\circ} \mathrm{C}\right)$ of kimberlitic pyroclastics and hypabyssal intrusions $\mathrm{s}^{2,10,11}$.

The pipe-formation process proposed by Wilson and Head is unclear, but we envisage that it involves the principles of rock mechanics ${ }^{2,12}$, combined with large early overpressures and later underpressures associated with explosive flows ${ }^{2}$. The geology supports a progressive, multistage and long-lived failure of wall-rocks by a variety of failure mechanisms rather than catastrophic pipe formation $^{2,12}$. The fluidization wave model of Wilson and Head is evidently a dynamic phenomenon. Fluidization is usually applied in geological systems using concepts from engineering ${ }^{13,14}$, in which gas flows continuously through unconsolidated granular materials. There is geological and experimental evidence that fluidization occurred in the waning pipe-filling stage of kimberlite eruptions ${ }^{2,13,14}$.

We agree with Wilson and Head that fast transport aids diamond preservation, but there are other important factors because kimberlites contain mixtures of perfectly shaped, broken and resorbed diamonds ${ }^{15}$, indicating diverse interaction histories with kimberlite magmas. Diamonds can be preserved within nodules, preventing reaction with kimberlite, and are released progressively during ascent by fragmentation of xenoliths, resulting in a range of interaction times $^{15}$.

\section{R. S. J. Sparks ${ }^{1}$, R. J. Brown ${ }^{1}$, M. Field ${ }^{1,2} \&$ M. Gilbertson ${ }^{3}$}

${ }^{1}$ Department of Earth Sciences, University of Bristol, Bristol BS8 1RJ, UK. e-mail: steve.sparks@bristol.ac.uk

${ }^{2}$ De Beers MRM Group, Wells, Somerset BA5 3DG, UK.

${ }^{3}$ Department of Mechanical Engineering, University of Bristol, Bristol BS8 1TR, UK.

\section{Received 26 July 2007; accepted 16 October 2007.}

1. Wilson, L. \& Head, J. W. III. An integrated model of kimberlite ascent and eruption. Nature 447, 53-57 (2007).

2. Sparks, R. S. J. et al. Dynamics of kimberlite volcanism. J. Volcanol. Geotherm. Res. 155, 18-48 (2006).

3. Lister, J. R. \& Kerr, R. C. Fluid-mechanical models of crack propagation and their application to magma transport in dykes. J. Geophys. Res. 96, 10049-10077 (1991).

4. Menand, T. \& Tait, S. R. The propagation of a buoyant liquid-filled fissure from a source under constant pressure: an experimental approach. J. Geophys. Res. 107, 2306 16-1-14 (2002).

5. Brooker, R. A., Kohn, S., Holloway, J. R. \& McMillan, P. F. Structural controls on the solubility of $\mathrm{CO}_{2}$ in silicate melts. Part I: bulk solubility data. Chem. Geol. 174, 225-239 (2001).

6. Mitchell, R. H. Kimberlites: Mineralogy, Geochemistry and Petrology (Plenum, New York, 1986).

7. Menand, T. \& Tait, S. R. A phenomenological model for precursor volcanic eruptions. Nature 411, 678-680 (2001).

8. Brown, R. J., Kavanagh, J., Sparks, R. S. J., Tait, M. \& Field, M. Mechanically disrupted and chemically weakened zones in segmented kimberlite dike systems cause the localisation of kimberlites. Geology 35, 815-818 (2007).

9. McLeod, P. \& Tait, S. R. The growth of dykes from magma chambers. J. Volcanol. Geotherm. Res. 92, 231-245 (1999)

10. Fedortchouk, Y. \& Canil, D. Intensive variables in kimberlite magmas, Lac de Gras, Canada and implications for diamond survival. J. Petrol. 45, 1725-1745 (2004).

11. Stripp, G., Field, M., Schumacher, J. C. \& Sparks, R. S. J. Post-emplacement serpentinisation and related hydrothermal metamorphism in a kimberlite from Venetia, South Africa. J. Metamorph. Geol. 24, 515-534 (2006).

12. Barnett, W. The rock mechanics of kimberlite pipe formation. J. Volcanol. Geotherm. Res. (in the press).

13. Walters, A. L. et al. The role of fluidisation in the formation of volcaniclastic kimberlite: grain size observations and experimental investigation. J. Volcanol. Geotherm. Res. 155, 119-137 (2006).

14. Gernon, T., Gilbertson, M. A., Sparks, R. S. J. \& Field, M. Gas-fluidisation in an experimental tapered bed: insights into processes in diverging volcanic conduits. J. Volcanol. Geotherm. Res. (in the press).

15. Gurney, J. in Kimberlites and related rocks: their mantle/crust setting, diamonds and diamond exploration. Proceedings of the Fourth International Kimberlite Conference. (eds Ross, J. et al.) Geol. Soc. Australia Special Publication, 14, 935-965, 990-1000 (Perth, Australia, 1989)

doi:10.1038/nature06435 


\section{Wilson \& Head reply}

Replying to: R. S. J. Sparks, R. J. Brown, M. Field \& M. Gilbertson Nature 450, doi:10.1038/nature06435 (2007).

Differences between the model of Sparks et al. ${ }^{1,2}$ and ours ${ }^{3}$ arise mainly because we focus on phenomena during the transient, opening phase that we suggest dominates many kimberlite eruptions, rather than on the subsequent, more prolonged phases relevant to other kimberlite eruptions ${ }^{1,2}$.

If water dominates carbon dioxide $\left(\mathrm{CO}_{2}\right)$ as the vapour phase ${ }^{1,2}$, our argument ${ }^{3}$ about the pressure distribution driving a kimberlite dyke to the surface is reinforced. The key factor allowing the initial rapid ascent is the large difference between the high mantle source pressure and the low dyke tip pressure, the latter being buffered by the saturation pressure of the least soluble volatile phase $e^{4,5}$. The dyke tip pressure required for water to exsolve will be even lower than the pressure we inferred for $\mathrm{CO}_{2}$, thus increasing the pressure difference driving the magma upward through the opening dyke.

Any vapour-filled region at the tip of a dyke, breaking away to propagate faster as an independent crack, can incorporate ${ }^{6}$ some of the magmatic foam implied by our model ${ }^{3}$. Cracks longer than $\sim 20 \mathrm{~m}$ travel at $\sim 1 \mathrm{~km} \mathrm{~s}^{-1}$, which is $\sim 40 \%$ of the sound speed in rock $^{7}$. Chilling of magma in the closing crack base 'heals' the fracture, restoring the country rock mechanical properties. When the dyke tip subsequently arrives, it encounters essentially the same conditions as if crack separation had never occurred. Only seconds are needed to chill a 1-2-mm-thick film of magma left behind by a $~ 20$-m-long crack; during this time the dyke tip, rising ${ }^{3}$ at $\sim 20 \mathrm{~m} \mathrm{~s}^{-1}$, travels $\sim 100 \mathrm{~m}-$ a tiny fraction of the dyke's vertical extent. A new low-pressure region starts to grow below the dyke tip immediately after crack separation; we infer that the stress and pressure conditions we proposed will be present over most of the path of the rising dyke tip.

Our dyke geometries are only slightly larger than those of Sparks et al. ${ }^{1,2}$, and their minimum estimates of total magma volumes imply eruption durations only a few times longer than the time to establish the dyke pathway ${ }^{3}$; larger volumes will imply more prolonged events. Our calculations $s^{3}$ of adiabatic cooling refer to magma reaching the surface during the opening phase of an eruption; in a long-lived eruption, most of the magma finally emplaced in the sub-surface diatreme will indeed suffer less cooling.
We suggested ${ }^{3}$ a violent change from overpressure to underpressure as a dyke reached the surface, with rapid physical development of the near-surface pipe and diatreme system. A longer-lived eruption ${ }^{1,2}$ will indeed allow a range of additional failure mechanisms. Although 'fluidization' commonly relates to the near-steady passage of gas through unconsolidated granular materials, as in the waning phases of kimberlite eruptions ${ }^{8}$, the basic physics is the same as that in our violent opening phase.

Regarding preservation of diamonds during transit to the surface, we stress ${ }^{3}$ that rapid transport will maximise the survival of diamonds as they pass through potentially unstable combinations of ambient pressure and temperature conditions, irrespective of the chemical environment that they encounter'.

Lionel Wilson ${ }^{1} \&$ James W. Head III ${ }^{2}$

${ }^{1}$ Environmental Science Department, Lancaster University, Lancaster LA1 4YQ, UK.

${ }^{2}$ Geological Sciences Department, Brown University, Providence, Rhode Island 02912, USA.

e-mail: james_head@brown.edu

1. Sparks, R. S. J. et al. Dynamics of kimberlite volcanism. J. Volcanol. Geotherm. Res. 155, 18-48 (2006).

2. Sparks, R. S. J., Brown, R. J., Field, M. \& Gilbertson, M. Kimberlite ascent and eruption. Nature 450, doi:10.1038/nature06435 (2007).

3. Wilson, L. \& Head, J. W. III. An integrated model of kimberlite ascent and eruption. Nature 447, 53-57 (2007).

4. Lister, J. R. \& Kerr, R. C. Fluid-mechanical models of crack propagation and their application to magma transport in dykes. J. Geophys. Res. 96, 10049-10077 (1991).

5. Rubin, A. M. Dikes vs. diapirs in viscoelastic rock. Earth Planet. Sci. Lett. 119, 641-659 (1993).

6. Menand, T. \& Tait, S. R. A phenomenological model for precursor volcanic eruptions. Nature 411, 678-680 (2001).

7. Dobran, F. Volcanic Processes - Mechanisms in Material Transport page 212 (Kluwer) Plenum, New York, 2001).

8. Walters, A. L. et al. The role of fluidisation in the formation of volcaniclastic kimberlite: grain size observations and experimental investigation. J. Volcanol. Geotherm. Res. 155, 119-137 (2006).

9. Ross, J. et al. (eds) Kimberlites and related rocks: their mantle/crust setting, diamonds and diamond exploration. Proceedings of the Fourth International Kimberlite Conference. Geol. Soc. Australia Special Publication, 14, 935-965, 990-1000 (Perth, Australia, 1989).

doi:10.1038/nature06436 